\title{
O PRAWIE WŁASNOŚCI W OKRESIE PRZEBUDOWY USTROJOWEJ W POLSCE PO 1989 R.
}

\section{Wprowadzenie}

Prawo własności jest tym prawem, które od wieków wciąż budzi zainteresowanie. Są jednak okresy szczególnego zainteresowania prawem własności. Historia wskazuje, że dziejowe przełomy polityczne, gospodarcze, zwykle doprowadzają do poważnej rewizji podstawowych instytucji prawnych, na których opiera się funkcjonowanie obrotu prawnego i gospodarczego. Można powiedzieć, że spośród wielu innych instytucji prawnych wykazujących dużą wrażliwość na przemiany ustrojowe wyróżnia się prawo własności.

W czasach stabilizacji prawo to, podobnie jak życie codzienne, zmienia się stopniowo, powoli, w sposób naturalny. Trafnie podkreślił A. Stelmachowski, że własność jest jednym z filarów, na którym wspiera się cała konstrukcja systemu prawa cywilnego. Bez niej „,...) byłaby trudna do pomyślenia dynamika obrotu, będąca nerwem cywilistyki" '.. Warto zauważyć, że z jednej strony własność jest najprostszą i bezpośrednią formą korzystania $\mathrm{z}$ dóbr materialnych, $\mathrm{z}$ drugiej strony, tylko w ramach własność istnieje możliwość korzystania z najszerszego znanego w systemie prawa zakresu uprawnień względem rzeczy.

Ponadto trzeba mieć na uwadze fakt, że własność nie jest kategorią tylko cywilistyczna, ma swoje ważne miejsce w innych obszarach prawa, np. w prawie finansowym, administracyjnym. Przede wszystkim termin ,własność” w praktyce konstytucyjnej państw demokratycznych wyraża jedno z powszechnych praw obywatelskich, a w układzie prawnomiędzynarodowym własności przyznać należy wartość jednego z podstawowych praw człowieka².

1 A. Stelmachowski, Zarys teorii prawa cywilnego, Warszawa 1998, s. 173.

2 A. Doliwa, Prawo rzeczowe, Warszawa 2004, s. 28. 
Nie ulega kwestii, że własność daleko wykracza poza obszar prawa. Bez własności trudno sobie wyobrazić ekonomię. Jest ona także kategorią socjologiczną, ma również swój aspekt psychologiczny³ ${ }^{3}$ Treść prawa własności zawsze była współkształtowana nie tylko przez normy prawa, ale także przez czynniki pozanormatywne, takie jak interesy władzy państwowej, czynniki ekonomiczne, obyczajowe i inne.

Zmianom podlegają warunki wykonywania prawa własności i jego treść, a za nimi także funkcje własności, na co zwrócił uwagę W. Pańko w monografii „O prawie własności i jego współczesnych funkcjach"4.

W okresie ustroju obowiązującego w PRL treść prawa własności była wyraźnie różnicowana w zależności od podmiotu, któremu to prawo przysługiwało. Odmienny stosunek kc. do poszczególnych typów i form własności znalazł swój wyraz zwłaszcza w przepisach ogólnych o własności, a mianowicie w odmiennym ujęciu reguł interpretacyjnych ${ }^{5}$. W myśl ówczesnej linii ustrojowej własność społeczna pozostawała pod szczególną ochroną prawa, a wiodącą zasadą prawa cywilnego była wyjątkowo niespójnie sformułowana zasada jedności własności państwowej, wyrażona w skreślonym w 1990 r. art. 128 § 1 kc. Niespójność była tak daleko idąca, że w roku 1980 w literaturze sformułowano wprost pytanie: Czy ,własność ogólnospołeczna” jest „własnością”?․ Przez fakt opanowania przez państwo działalności gospodarczej wyrażała się zasada nierozerwalności i niepodzielności połączenia władzy państwowej z uprawnieniami właściciela.

Należy podkreślić, że treść art. 140 kc. określająca pojęcie własności pozostaje przez cały czas niezmienna. Zgodnie z tym przepisem w granicach określonych przez ustawy i zasady współżycia społecznego właściciel może, z wyłączeniem innych osób, korzystać z rzeczy zgodnie ze społeczno-gospodarczym przeznaczeniem swego prawa, w szczególności może pobierać pożytki i inne dochody z rzeczy. W tych samych granicach może rozporządzać rzeczą.

Mimo niezmienionej treści art. 140 kc. po 1989 r. doszło do przewartościowania w zakresie funkcji oraz wykonywania prawa własności i jej kategoryzacji. Obecnie w Polsce na pierwszy plan wysuwa się ogólna stratyfikacja własności na własność publiczną i własność prywatna. Podział ten jest pochodny, bo wywodzi się od zasadniczego podziału prawa na prawo prywatne i prawo publiczne i ma swe korzenie w prawie rzymskim ${ }^{7}$. Ma on przede wszystkim charakter funkcjonalny, chociaż

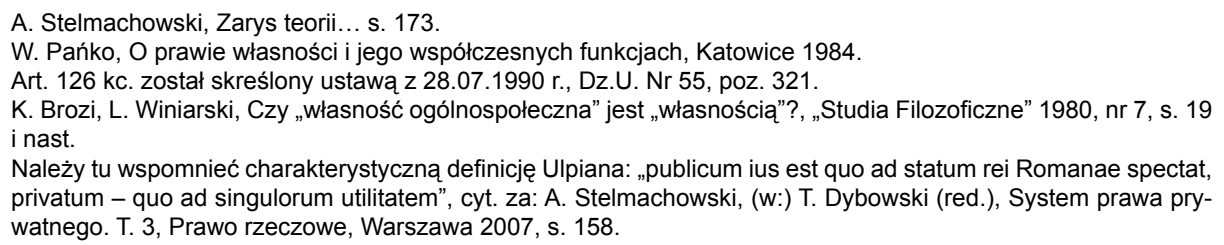
privatum - quo ad singulorum utilitatem", cyt. za: A. Stelmachowski, (w:) T. Dybowski (red.), System prawa prywatnego. T. 3, Prawo rzeczowe, Warszawa 2007, s. 158. 
i element podmiotowy odgrywa tu swoistą rolę. Zgodnie z tym założeniem własność publiczna powinna być wykonywana przez te podmioty prawa, które do zadań publicznych są powołane, a więc państwo i samorząd terytorialny. Punktem odniesienia jest funkcja, a nie strona podmiotowa ${ }^{8}$. Ponadto w literaturze zauważa się, że „wyodrębnienie własności publicznej nastąpiło po rozdzieleniu skarbu panującego na publiczny i prywatny"'.

W aktualnie obowiązujących warunkach ustrojowych w Polsce fundamentem gospodarki i podstawą uczestnictwa w obrocie prawnym i gospodarczym jest własność prywatna. Własność prywatna jest kategorią modelową w gospodarce rynkowej i blisko wiąże się z zasadą wolności działalności gospodarczej, co wynika przede wszystkim z art. 20 Konstytucji $\mathrm{RP}^{10}$.

Kluczowe znaczenie w przemianach ustrojowych zajął trudny proces przekształceń własnościowych. Rozmiary państwowej gospodarki zmieniano przez zmniejszenie liczby przedsiębiorstw państwowych w drodze ich likwidacji i upadłości oraz przekształcania w jednoosobowe spółki Skarbu Państwa, a także w drodze komercjalizacji i prywatyzacji przedsiębiorstw państwowych. Wszystkie te działania wymagały określonego czasu. Uchwalenie ustaw dotyczących przekształceń własnościowych to dopiero początek procesu przebiegającego na wielu płaszczyznach życia społecznego. Czynnik czasu odgrywa istotną rolę, tak w procesie prywatyzacji przedsiębiorstw państwowych poprzez przygotowanie ich do poddania działaniom praw rynku, jak i w procesie budowania materialnej podstawy dla powstania i funkcjonowania własności komunalnej, uwłaszczenia i nadania jednostkom samorządu terytorialnego osobowości prawnej. W pierwszym rzędzie procesom uwłaszczeniowym poddano gminy i inne komunalne osoby prawne, które w dniu 27.05.1990 r. nabyły z mocy prawa albo na podstawie konstytutywnej decyzji właściwego wojewody własność należącego do nich mienia, mienia znajdującego się w ich zarządzie $^{11}$. Następnie w 1998 r. wydano podstawowe ustawy dotyczące samorządów wojewódzkich i powiatowych ${ }^{12}$.

Własność stała się ważnym instrumentem prawnym na drodze ,z powrotem do kapitalizmu"13. Procesu tego nie da się zakwalifikować w ramy tradycyjnie rozumianego obrotu prawnego polegającego na wymianie dóbr i usług. Własności przypad-

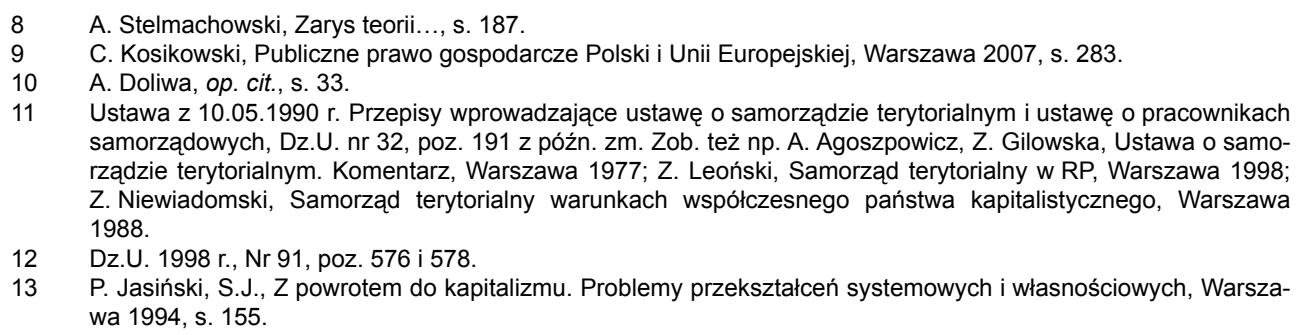
samorządowych, Dz.U. nr 32, poz. 191 z późn. zm. Zob. też np. A. Agoszpowicz, Z. Gilowska, Ustawa o samorządzie terytorialnym. Komentarz, Warszawa 1977; Z. Leoński, Samorząd terytorialny w RP, Warszawa 1998; Z. Niewiadomski, Samorząd terytorialny warunkach współczesnego państwa kapitalistycznego, Warszawa 1988.

12 Dz.U. 1998 r., Nr 91, poz. 576 i 578.

13 P. Jasiński, S.J., Z powrotem do kapitalizmu. Problemy przekształceń systemowych i własnościowych, Warszawa 1994, s. 155. 
ła więc rola szczególna, nietypowa. Równolegle następowały dwa procesy głęboko dotyczące prawa własności i własności jako kategorii także pozaprawnej, przede wszystkim ekonomicznej i społecznej.

Pierwszy proces polegał na przywracaniu prawu własności jej klasycznej treści, między innymi poprzez usuwanie elementów temu prawu obcych, tych, które zostały „wmontowane” w okresie PRL, np. zasady jedności własności państwowej. Drugi proces to przebudowa ustrojowa, prowadzona poprzez przekształcenia własnościowe. W czasie przekształceń własnościowych nie został jednak realizowany istotny problem reprywatyzacji.

\section{Wpływ przemian ustrojowych na rozwój regulacji prawnych stosunków własnościowych}

Model ustroju polityczno-gospodarczego i kształt stosunków własnościowych wzajemnie się determinują, choć przyznać trzeba, że nie brak w tym względzie innych poglądów ${ }^{14}$. Radykalne przemiany ustrojowe wiążą się więc z głębokimi przeobrażeniami w sferze własności rozumianej szerzej, a więc nie tylko w wymiarze prawa cywilnego ${ }^{15}$. W Polsce przełom polityczny w 1989 roku zapoczątkował proces istotnych zmian ustrojowych. Rozpoczęła się budowa gospodarki rynkowej i ważny etap tego procesu, czyli przekształcenia własnościowe. W tym celu uchwalono szczególne regulacje prawne ${ }^{16}$.

Przyjmując, że własność jest kategorią interdyscyplinarną, trzeba konsekwentnie stwierdzić, że przemiany w płaszczyźnie prawnej, ekonomicznej pociagnęły za sobą zmiany także w sferze zjawisk socjologicznych, psychologicznych i wielu innych dziedzinach nauki i praktyki. Dotyczą więc one zarówno poszczególnych obywateli, grup społecznych, jak też i skali całego kraju. Czas, jaki upłynął od przełomu politycznego, stał się czasem przewartościowań, który przyniósł ze sobą nie tylko zjawiska pozytywnie oceniane, ale także te o charakterze dysfunkcjonalnym, takie jak problem likwidacji przedsiębiorstw nierentownych, bezrobocie, trudne często wywołujące wiele negatywnych zjawisk relacje między sferą polityki i gospodarki i wiele innych.

\footnotetext{
14 Niektórzy przedstawiciele nauk ekonomicznych i społecznych dowodzili braku zależności między typem własności a charakterem ustroju społeczno-gospodarczego, nawiązują oni do teorii tzw. „społeczeństwa przemysłowego", zob. W. Rostow, Studia rozwoju ekonomicznego, aron R., Dix-huit lecons sur la sociéte industrielle. Huit lecons de la societe industrielle, Paris 1962.

15 M. Bednarek, Koncepcja własności w dobie transformacji ustrojowej w Polsce, „Kwartalnik Prawa Prywatnego” 1993, z. 4, s. $447,448$.

16 Ustawa z 13.07.1990 r. o prywatyzacji przedsiębiorstw państwowych, Dz.U. Nr 51, poz. 298 oraz ustawa z 30.08 1996 r., o komercjalizacji i prywatyzacji przedsiębiorstw państwowych, Dz.U. Nr 118, poz. 561 z późn. zm.
} 
Po odrzuceniu koncepcji własności przyjętej w Konstytucji PRL ustawodawca stanął przede wszystkim przed koniecznością przywrócenia kształtu własności adekwatnej do budowanej gospodarki rynkowej. W tym celu zostały podjęte działania legislacyjne w wielu obszarach dotyczących stosunków własnościowych i samego prawa własności. Wśród tych działań najsilniej uwidacznia się nurt prywatyzacyjny, nazywany niekiedy procesem generalnego „odpaństwowienia” własności.

Reformę stosunków własnościowych rozpoczęto od zmiany przepisów konstytucyjnych i przepisów kodeksu cywilnego, bowiem w tych aktach prawnych znajdujemy podstawy dalszych regulacji stosunków własnościowych.

Ustawą z 29.12.1989 r. o zmianie Konstytucji RP ${ }^{17}$, w miejsce „socjalistycznej” koncepcji własności wprowadzono zasadę równouprawnienia wszystkich podmiotów biorących udział w obrocie prawnym i gospodarczym. Skreślone zostały przepisy związane z obowiązującą dyferencjacją własności, te, które ustanawiały przywileje dla własności społecznej.

Idąc za zmianami w Konstytucji, ustawodawca dokonał nowelizacji kodeksu cywilnego. W 1990 roku uchylił przepisy art. 126-135, będące konsekwencją poprzednich konstytucyjnych uregulowań własności, opartych na marksistowskiej typizacji. Wyeliminowano też z kodeksu cywilnego przepisy traktujące o jednostkach gospodarki uspołecznionej, zrezygnowano z szeregu przywilejów na gruncie prawa cywilnego materialnego i procesowego przewidzianych dla jednostek funkcjonujących w oparciu o własność społeczną, a zwłaszcza państwowa. ${ }^{18}$

Wśród zasadniczych zmian przepisów dotyczących stosunków własnościowych znajdują się także wcześniej wspomniane regulacje dotyczące problematyki własności samorządowej (komunalnej).

Zasygnalizowane tu zmiany przepisów konstytucyjnych i przepisów z zakresu prawa cywilnego, a następnie uchwalenie ustawy o prywatyzacji przedsiębiorstw państwowych mogłoby wskazywać, że ustawodawca dążył do ustanowienia jednolitego, abstrakcyjnego modelu własności. Hipoteza taka jest jednak kontrowersyjna. Należy zgodzić się z poglądem, że uniwersalny model prawa własności należy już do przeszłości. ${ }^{19} \mathrm{~W}$ najbardziej wyrazistej postaci występował on w okresie kształtowania się ustroju kapitalistycznego w dziewiętnastym wieku.

W hierarchicznej, stanowej strukturze społecznej feudalizmu władza splatała się niemal nierozerwalnie z własnością. Burżuazja, zdobywając władzę ekonomiczną, musiała znieść zhierarchizowaną własność stanową. Zastąpiła ją uniwersalnym, nie-

Dz.U. nr 75, poz. 444, zob. także A. Lityński, O prawie i sądach początków Polski Ludowej, Białystok 1999, s. $240 \mathrm{in}$.

Dz.U. 1990 r., Nr 55, poz. 321 i 318.

M. Bednarek, Koncepcja własności..., s. 451 i 452, na temat innych teorii własności zob. W. Biegeleisen, Teoria małej i wielkiej własności. Referat na VI zjazd prawników i ekonomistów polskich, Kraków 1918. 
zależnym od podmiotu i przedmiotu modelem prawa własności, podkreślając niezależny od władzy państwowej charakter prawa własności. ${ }^{20}$

Państwo burżuazyjne, przestrzegając rozdziału między władzą polityczną i prawem własności, gwarantowało wolne pole dla kształtowania się produkcyjnych stosunków między kapitałem i pracą najemną. Ów stan formalnej rozdzielności nie mógł być jednak utrzymany ze względu na zaostrzające się sprzeczności wśród właścicieli środków produkcji, m.in. konflikty związane z rozrostem monopoli, a również z wzrastającą rolą i żądaniami robotników. Interwencjonizm państwowy, wkraczając w sferę prawa własności, służył zachowaniu „pokoju klasowego”, a rewizja „świętego prawa własności” odbywała się pod hasłem obrony interesu społecznego. ${ }^{21}$

W obecnych warunkach funkcjonowania społeczeństwa i gospodarki nie dałoby się obronić hipotezy, że zmiany szeregu przepisów w związku z przekształceniami własnościowymi mogą oznaczać powrót do własności prywatnej w sensie uniwersalnego modelu własności. Dodać przy tym należy, że nie ma legalnej definicji pojęcia „własność prywatna”, chociaż posługuje się nim ustawodawca. Ponadto jest to kategoria często rozważana $\mathrm{w}$ sferze nauki ${ }^{22}$.

Zaznaczyć jednak należy, że niektórzy przedstawiciele nauki wskazywali wręcz, że termin „własność prywatna” używany jest jedynie dla zaakcentowania negatywnego stosunku do marksistowskiego pojęcia własności. Podkreślali, że jest on tylko opozycją do terminu „własność społeczna” i nie ma dalej idącego samoistnego znaczenia $^{23}$. Czas wykazuje, że pojęcie to od dawna funkcjonuje w języku potocznym, a w literaturze przedmiotu coraz częściej także znajduje swoje poczesne miejsce.

Wydaje się, że w Polsce można już mówić co najmniej o początkach doktrynalnego kształtowania się własności prywatnej jako osobnej prawnej kategorii własności. Pozostając przy bardziej ostrożnym stanowisku co do kategorii własności prywatnej, nie sposób pominąć ciekawego poglądu wygłoszonego przez S. Wójcika, który stwierdził, że obowiązujące przepisy nie stoją na przeszkodzie wyodrębnieniu już na gruncie legis late własności prywatnej, jako osobnej kategorii własności ${ }^{24}$. Składa się na nią własność środków produkcji osób fizycznych oraz własność osób prawnych innych niż państwowe i komunalne.

Można przyjąć koncepcję własności prywatnej, którą zaprezentował S. Wójcik, stwierdzając, że na własność prywatną składa się własność środków produkcji osób fizycznych oraz własność osób prawnych innych niż państwowe i komunalne.

\footnotetext{
20 W. Pańko, O prawie własności..., s. 50.

21 Ibidem, s. 51

22 S. Wójcik, Problem pojęcia „własność prywatna” w III Rzeczypospolitej, „Rejent” 1991, nr 7-8, s. 7 i n.

23 M. Bednarek, Koncepcja własności..., s. 452 i 453.

24 S. Wójcik, Problem pojęcia..., s. 14.
} 
Nietrudno zauważyć, że poza teoretycznymi rozważaniami pojęcie „własność prywatna" występuje w ustawodawstwie. Kluczowe znaczenie ma tu art. 20 Konstytucji RP operujący pojęciem „własność prywatna”. Ustawa Zasadnicza nie wyjaśnia jednak tego pojęcia. W art. 64 Konstytucja, już nie określając rodzaju własności, mówi, że każdy ma prawo do własności, innych praw majątkowych oraz prawo dziedziczenia. Własność, inne prawa majątkowe oraz prawo dziedziczenia podlegają równej dla wszystkich ochronie prawnej.

Mogłoby wydawać się, że poszukując odpowiedzi na pytanie, co to jest własność prywatna, jaka własność, do kogo należąca jest własnością prywatną, należałoby sięgnąc do przepisów o prywatyzacji, znajdujących się w obu ustawach prywatyzacyjnych. Można bowiem twierdzić, że prywatyzacja przedsiębiorstw państwowych zdefiniowana w art. 1 ustawy o prywatyzacji przedsiębiorstw państwowych i w art. 1 ust. 2 ustawy o komercjalizacji i prywatyzacji przedsiębiorstw państwowych jest jednym ze sposobów powstania (nabycia) własności prywatnej.

Zgodnie z art. 1 ustawy o prywatyzacji przedsiębiorstw państwowych prywatyzacja polegała na udostępnieniu osobom trzecim akcji lub udziałów w spółkach z wyłącznym udziałem Skarbu Państwa, powstałych z przekształcenia przedsiębiorstwa państwowego, na udostępnieniu osobom trzecim mienia przedsiębiorstwa albo sprzedaży osobom trzecim przedsiębiorstwa. Z samego ogólnego rozumienia prywatyzacji można wnosić, że prywatyzacja powinna następować na rzecz osoby fizycznej albo na rzecz osoby prawnej innej niż państwowa. Jak się okazuje, sprawa nie jest prosta, gdyż nie ma jednoznacznej odpowiedzi na pytanie, jakie podmioty funkcjonujące w sferze obrotu gospodarczego należy uważać za państwowe osoby prawne. $Z$ pewnością są nimi przedsiębiorstwa państwowe jako forma prawna państwowej działalności gospodarczej ${ }^{25}$. Warto zwrócić uwagę na pogląd G. Romańskiego, który stwierdził, że zaistnienie w spółce chociażby jednego niepaństwowego podmiotu jako akcjonariusza lub udziałowca jest równoznaczne $\mathrm{z}$ utrata jej państwowego charakteru. ${ }^{26} \mathrm{~W}$ tej sytuacji pojawia się pytanie: Czy przyjęcie, że spółka kapitałowa z najmniejszym chociażby udziałem kapitału innego niż państwowy już nie jest państwową osobą prawną, oznacza zupełnie nową jakość, a idąc dalej oznacza, że jest osobą prawną, którą należy traktować jak przedsiębiorcę opierającego swoją działalność o własność prywatną? Sądzić należy, że udzielenie twierdzącej odpowiedzi mijałoby się generalnie z celami prywatyzacji jako procesu wykraczającego poza ramy tylko zmiany właściciela, chociaż w takim przypadku trudno byłoby także mówić o faktycznej zmianie własności. 
Przepisy obu ustaw prywatyzacyjnych wyeksponowały raczej „techniczną”, proceduralną stronę „odpaństwowienia” przedsiębiorstwa państwowego. Nie ma w nich generalnej konstrukcji prawnej co do pojęcia i treści własności prywatnej.

Skądinąd jest to usprawiedliwione, bowiem ideą przepisów prywatyzacyjnych nie jest zbudowanie teoretycznej konstrukcji własności prywatnej, lecz stworzenie bazy prawnej do przeprowadzenia rozciągniętego w czasie procesu strukturalnowłasnościowych przemian w gospodarce narodowej, dotychczas opartej na własności państwowej.

Uwzględniając fakt, że prywatyzacja wypływa przecież z określonych politycznych uwarunkowań, warto przytoczyć opinię, jaką swego czasu wygłosił W. Pańko, mówiąc o roli prawa i polityki w kształtowaniu stosunków własnościowych. Jego zdaniem ,głównym czynnikiem różnicowania się poglądów na temat istoty i struktury prawa własności jest ideologiczne (polityczne) zróżnicowanie koncepcji własności.” Autor zauważył też, że „(...) prawna formuła własności środków produkcji musi uwzględniać nie tylko sprawiedliwe założenia ideowe, ale i efektywność w sferze produkcji (...). Ten ostatni czynnik jest szczególnie bezwzględnym weryfikatorem racjonalności regulacji prawnej stosunków własnościowych, wskazuje też stopień zgodności ekonomicznych treści i prawnych form własności.”27

Można przyjąć koncepcję własności prywatnej, którą zaprezentował S. Wójcik, stwierdzając, że na własność prywatną składa się własność środków produkcji osób fizycznych oraz własność osób prawnych innych niż państwowe i komunalne.

\section{Stosunki własnościowe a charakter uczestnictwa państwa w życiu gospodarczym}

Bazą stosunków własnościowych w gospodarce jest dziś art. 20 Konstytucji RP, z którego wynika, że społeczna gospodarka rynkowa oparta jest na wolności działalności gospodarczej i własności prywatnej. Charakterystyczne jest, że Konstytucja nie wyróżnia własności państwowej, co nie może oznaczać, że nie ma obecnie dylematu istnienia własności państwowej i zakresu udziału państwa w gospodarce.

Odpowiedź na pytanie: jak daleko państwo może ingerować w wykonywanie prawa własności jego obywateli, jakimi sprawami w sferze gospodarki powinno zajmować się państwo, a jakie powinny być zupełnie wyłączone spod ingerencji państwa, nie jest łatwa i jednoznaczna. Problem ten od wielu lat jest przedmiotem dyskusji w różnych środowiskach naukowych i jak dotychczas nie ma w tej kwestii jednolitych poglądów ani koncepcji funkcjonowania własności państwowej. 
Państwo uczestniczy w życiu gospodarczym kraju w różny sposób. W szczególności państwo ustanawia i egzekwuje pewne reguły „współistnienia” podmiotów prowadzących działalność gospodarczą. Celem więc działań państwa jest z jednej strony ochrona szeroko pojmowanego porządku publicznego, z drugiej zaś - realizacja określonych długotrwałych celów, takich jak np. pobudzanie koniunktury, stabilizacja pieniądza, ograniczenie bezrobocia itp. Działalność państwa w tym zakresie jest traktowana jako jedno z najważniejszych, oczywistych zadań ${ }^{28}$.

Kolejnym przejawem uczestnictwa państwa w życiu gospodarczym jest jego bezpośrednia działalność gospodarcza, w ramach której państwowe jednostki organizacyjne występują na rynku. Zakres bezpośredniej działalności gospodarczej jest w poszczególnych krajach różny. Zmienia się również w czasie, na co mają wpływ czynniki tak ekonomiczne, jak i polityczne.

Zdaniem J. Frąckowiaka ${ }^{29}$ w Polsce obecnie ważne miejsce w kategorii państwowych osób prawnych zajmują jednoosobowe spółki Skarbu Państwa, powstałe z przekształcenia przedsiębiorstw państwowych. Oprócz przedsiębiorstw państwowych i jednoosobowych spółek Skarbu Państwa polski porządek prawny zna jeszcze inne państwowe osoby prawne, których przedmiot działalności polega na prowadzeniu wyspecjalizowanej działalności gospodarczej. Zaliczyć do nich można banki państwowe, jednostki badawczo-rozwojowe, liczne agencje, fundusze. Państwowe osoby prawne mają własne odrębne regulacje, które przede wszystkim określają wzajemne relacje między nimi a Skarbem Państwa. Zgodnie z definicją ustawową, państwową osobą prawną jest jednostka organizacyjna, której mienie jest w całości mieniem państwowym ${ }^{30}$. Z punktu widzenia czysto formalnego do kategorii państwowych osób prawnych nie można zaliczyć jednostki organizacyjnej, których mienie, chociażby w minimalnym stopniu, należy do innych podmiotów niż Skarb Państwa. W aspekcie praktycznym trudno byłoby uznać, że poprzez niewielki udział w spółce innego kapitału niż państwowy własność państwowa straci cechy swoiste dla własności publicznej.

Przegląd literatury prawniczej pozwala stwierdzić, że bezpośrednia działalność gospodarcza państwa jest przedmiotem trwających od lat dyskusji, kontrowersji na różnych płaszczyznach. ${ }^{31}$ Wśród przedstawicieli nauk prawnych dyskusyjna jest zwłaszcza kwestia legitymacji prawnej państwa do prowadzenia działalności go-

A. Walaszek-Pyzioł, Działalność gospodarcza sektora publicznego w ustawodawstwie o doktrynie Republiki Federalnej Niemiec, PUG 1994, s. 3, s. 21.

J. Frąckowiak, (w:) M. Safjan (red.), System Prawa Prywatnego. T. 1. Prawo cywilne - część ogólna, Warszawa 2007, s. 1065.

Art. 1a ustawy z 8.08.1996 r., o zasadach wykonywania uprawnień przysługujących Skarbowi Państwa, Dz.U. nr 106, poz. 493 z późn. zm.

Zob. m.in. A. Heydel, T. Lulek, S. Schmidt, S. Wyrobisz, F. Zweig, Etatyzm w Polsce, Warszawa 1936; T. Bernadzikiewicz, Przerosty etatyzmu, Warszawa 1936; tenże, Zagadnienie rentowności gospodarki państwowej, Warszawa 1932; tenże, Udział państwa w spółkach handlowych, Warszawa 1938. 
spodarczej. Często podnoszony jest argument zagrożenia praw prywatnych przedsiębiorców oraz zasady wolności gospodarczej, własności prywatnej w sytuacji, gdy państwo zajmuje się bezpośrednio działalnością gospodarczą.

W określonych sferach życia gospodarczego państwo z różnych względów zachowuje swój udział. Udział ten jest różny i służy różnym celom. Trzeba jednak mieć na uwadze okoliczność, że zbyt duże i nieuzasadnione względami społecznymi lub ekonomicznymi zaangażowanie państwa w prowadzenie działalności gospodarczej może naruszać wykonywanie własności przez przedsiębiorców opierających swą działalność na własności prywatnej. Należy podkreślić, że w Polsce, tradycyjnie, najczęściej podstawą do korzystania z danego dobra zarówno w obrocie powszechnym, jak i profesjonalnym jest prawo własności.

Ustalenie racjonalnych granic między sferą państwową i prywatną ciagle stwarza nowe problemy. ${ }^{32}$ Można jednak powiedzieć, że ustalenie stałej, niezmiennej granicy z wielu względów nie wydaje się w praktyce możliwe.

Doświadczenia, zwłaszcza ostatnich dziesięcioleci, dobitnie wykazały, że gospodarka oparta na własności państwowej skazana jest na niepowodzenie, ,(...) państwo, zawsze wielki konsument, będzie zawsze tylko złym producentem". ${ }^{33}$ Mają już swoją historię opinie, że państwo, prowadząc działalność gospodarczą, nie może ze swej natury przyjąć zasad funkcjonowania gospodarki prywatnej. ${ }^{34}$ Dziś są one wielokrotnie potwierdzane przez ekonomistów, prawników, socjologów.

Teoria praw własnościowych głosi, że różne formy własności dają początek różnym bodźcom ekonomicznym, a przez to prowadzą do różnych wyników ekonomicznych. Zdaniem J. Tittenbruna forma własności przesądza o wyborach kierunków działania podmiotów ekonomicznych. ${ }^{35}$ Wydaje się, że z perspektywy doświadczeń gospodarki socjalistycznej można dziś rozbudować tę tezę i stwierdzić, że własność państwowa hamuje przedsiębiorczość, wymusza takie formy prawne prowadzenia działalności gospodarczej, które dają możliwość prymatu ideologii i polityki nad podstawowymi regułami ekonomii.

Jeśli mówiąc o własności, oddzielimy od siebie ideę własności oraz jej treść, to można wówczas zauważyć, że w okresach przełomowych, w okresach kształtowania się nowych struktur społeczno-gospodarczych, większe zainteresowanie budzi sfera treści i funkcji własności niż idea prawa własności. Przedstawiciele doktryny

\footnotetext{
32 A. Walaszek-Pyzioł, Działalność gospodarcza..., s. 21 i n.

33 S.Z. Szyszkowski, Zagadnienie komercjalizacji przedsiębiorstw państwowych, Warszawa 1930, s. 15.

34 A. Schatz, L'entreprise gouvernmentale et son administration, Paris 1922, cytuję za S.Z. Szyszkowski, Zagadnienie komercjalizacji..., s. 16.

35 J. Tittenbrun, Teoria wolnodostępnej własności, RPEiS 1996, nr 2, s. 123 i n.
} 
prawa podkreślają taką właśnie prawidłowość, jak również to, że sama idea prawa własności charakteryzuje się dużą stabilnością. ${ }^{36}$

W ujęciu modelowym idea prawa własności rozumiana jest jako przypisanie określonej osobie lub grupie osób domniemania wyłączności korzystania i dysponowania rzeczami bądź innymi dobrami. Przyjmując ten pogląd, należy również zgodzić się z opinią, że trwałości idei własności nie powinno utożsamiać się z własnością prywatną $\mathrm{w}$ rozumieniu dziewiętnastowiecznym ani też z żadnym innym konkretnym modelem ideowym własności lub konkretną konstrukcją normatywną tego prawa ${ }^{37}$.

Wyodrębniając więc ideę prawa własności i jej treść, można powiedzieć, że treść prawa własności i funkcje ulegają zmianom w zależności m.in. od kontekstu społeczno-gospodarczego, od czasu, miejsca i od podmiotu wykonującego prawo własności.

\section{Uwagi końcowe}

Na przestrzeni ostatnich dziesięcioleci wyraźnie widać, jak zasadniczy wpływ na własność ma czas przemian ustrojowych. Dotyczy to własności jako kategorii interdyscyplinarnej, zwłaszcza ekonomicznej i socjologicznej, a także prawa własności w wymiarze normatywnym.

Zastanawiając się nad współczesną stratyfikacją własności w Polsce, należy zauważyć, że w miejsce stosowanego w PRL podstawowego podziału własności na własność społeczną (ze szczególnym wyróżnieniem własności państwowej) i własność indywidualną przyjęty został podział na własność prywatną i własność publiczną ${ }^{38}$, akcentujący odmienności zachodzące miedzy społecznym a jednostkowym punktem widzenia prawa własności. Trafna jest uwaga A. Stelmachowskiego, że niezależnie od tego podziału, coraz większego znaczenia nabiera funkcjonalne zróżnicowanie własności uwzględniające przedmiot własności ${ }^{39}$. W tym aspekcie Autor wymienił własność rolniczą, własność zasobów leśnych, własność zasobów naturalnych, własność zasobów mieszkaniowych ${ }^{40}$, własność intelektualną, własność przemysłową, własność dóbr kultury stanowiących dziedzictwo narodowe ${ }^{41}$. ności, (w:) S. Prutis (red.), Przekształcenia własnościowe w Polsce. (determinanty prawne), Białystok 1996, s. 15.

37 W. Pańko, O prawie własności... s. 15.

38 Zob. szerzej na ten temat np. J. Szachułowicz, Własność publiczna, Warszawa 2000.

39 A. Stelmachowski, (w:) T. Dybowski (red.), System Prawa Prywatnego..., s. 186.

40 Zob. szerzej na ten temat, np. M. Bednarek, Prawo do mieszkania w konstytucji i w ustawodawstwie, Warszawa 2007.

41 A. Stelmachowski, (w:) T. Dybowski (red.), System Prawa... s. 187. 
Po 1989 r. przedstawiciele nauki stanęli przed dylematem: jak właściwie rozumieć dziś własność państwową ${ }^{42}$. W dyskusjach nad tą kwestią pojawia się zasada podzielności własności państwowej zasadniczo odmienna od tej, która wynikała $\mathrm{z}$ art. $128 \mathrm{kc}$. Zgodnie $\mathrm{z}$ art. $44^{1} \S 1 \mathrm{kc}$. własność i inne prawa majątkowe, stanowiące mienie państwowe, przysługują Skarbowi Państwa albo innym państwowym osobom prawnym.

W zależności od kontekstu gospodarczego i społecznego poszczególne rodzaje własności odgrywają różną role i różna jest dynamika zmian ilościowych i jakościowych w obrębie tych rodzajów własności.

Czas wskazuje, że sprawdza się koncepcja i funkcjonowanie własności komunalnej. Własność ta ma charakter specyficzny, uwarunkowany interesem publicznym $^{43}$, jej celem jest realizacja ustawowo określonych zadań, jak i sposobów gospodarowania własnością samorządową ${ }^{44}$. Inaczej przedstawia się kwestia własności państwowej. Mimo upływu ponad dwudziestu lat od rozpoczęcia procesu zasadniczych przewartościowań w obszarze własności państwowej, wciąż pojawia się wiele kwestii, które nie zostały rozwiązane we właściwym czasie, np. problemy reprywatyzacji. Pojawia się tu pytanie, czy procesu przekształceń własnościowych nie należało rozpocząć od reprywatyzacji? Ciagle jest to problem żywo dyskutowany i dostrzegany nie tylko przez osoby mieszkające w Polsce, ale i w innych krajach, których obywatele zostali wyzuci z prawa własności przez władze PRL.

Generalnie wszystkie te rodzaje własności łączą uprawnienia właścicielskie, jak i obowiązki związane z prawem własności, czyli prawo do korzystania i rozporządzania w granicach wyznaczonych przez art. 140 kc. i inne przepisy. Należy podkreślić, że sytuację prawną właściciela kształtują nie tylko prawa i obowiązki wynikające z prawa prywatnego, ale także prawa, a w jeszcze większym stopniu obowiązki natury publicznoprawnej ${ }^{45}$.

Specyfika przedmiotu stosunku prawnego własności przejawia się przede wszystkim w tym, ,że stanowiące ten przedmiot dozwolone zachowanie właściciela odbywa się w strefie przestrzennej oznaczonej skutecznie erga omnes, w przestrzeni niejako publicznie zagwarantowanej" ${ }^{46}$. W żadnym razie nie może to jednak oznaczać, że ta strefa może być kształtowana niezależnie od treści prawa własności. W związku z tym tak ważne znaczenie ma zachowanie właściwej proporcji między

\footnotetext{
42 W.J. Katner, Rozwiązania prawne i przebieg prywatyzacji w Polsce, (w:) Studia z prawa gospodarczego i handlowego. Księga pamiątkowa ku czci Profesora Stanisława Włodyki, Kraków 1996, s. 216.

43 Z uzasadnienia wyroku TK z 9.01.1996 r., K 18/95, OTK 1996, nr 1, poz. 1 oraz P. Wagner, Własność komunalna. Zagadnienia węzłowe, „Samorząd Terytorialny” 1998, nr 1-2, s. 25.

44 T. Dębowska-Romanowska, Prawo finansowe. część konstytucyjna wraz z częścią ogólna, Warszawa 2010, s. 230 i nast. także M. Szydło, Ustawa o gospodarce komunalnej. Komentarz, Warszawa 2008.

45 A. Stelmachowski, (w:) T. Dybowski (red.), System Prawa..., s. 161.

46 W. Pańko, Własność gruntowa w planowej gospodarce przestrzennej. Studium prawne, Katowice 1978, s. 51.
} 
uprawnieniami i obowiązkami wynikającymi z prawa własności, a także zagwarantowanie oraz realizacja ochrony własności jako podstawowego prawa naturalnego.

W praktyce prawnego obrotu powszechnego i profesjonalnego prawo własności jest powiązane $z$ wieloma zasadami i instytucjami prawnymi. $Z$ reguly są to powiązania z oddziaływaniem wzajemnym. W gospodarce rynkowej chyba najbardziej wyrazisty jest związek między wykonywaniem prawa własności a zasadą wolności umów i zasadą wolności gospodarczej.

W czasach stabilizacji ustrojowej i gospodarki rynkowej prawo to działa na poziomie podstawowym, zaspakaja potrzeby dnia codziennego, tak w obrocie powszechnym, jak i profesjonalnym. Można powiedzieć, że jest to naturalna, klasyczna funkcja prawa własności.

W okresie przekształceń ustrojowych w Polsce po 1989 r. własność i prawo własności spełniły rolę dla siebie nietypową. Prawo własności stało się kluczowym instrumentem prawnym przekształceń ustrojowych, torującym unikalny w dotychczasowej historii kierunek ,z powrotem do kapitalizmu”. 


\title{
THE PROPERTY LAW DURING THE RECONSTRUCTION OF POLITICAL SYSTEM IN POLAND AFTER 1989
}

\author{
SUMMARY
}

Although the construction of property law in article 140 of civil law code has not changed, the rules of execution of the property and the function of this basic natural law which is due to human being, have been undergoing gradual change.

This law has dynamic character which is dependent not only on the legal system but also on the political, economic and social environment.

These three factors affect one another as a rule.

Now, as a result of political change and long term privatization processes, individual property has become the base of the political and economical system.

In functional terms, property law is not heterogeneous, although it is based on the classical scheme derived from Roman law.

For property law, the maintaining of proper proportions between rights and obligations resulting from this law is crucial.

In particular, destabilization of property law may result from excessive interference of the state in the execution of this law.

In practice, this interference is done mainly through extending different obligations of public and legal nature. 